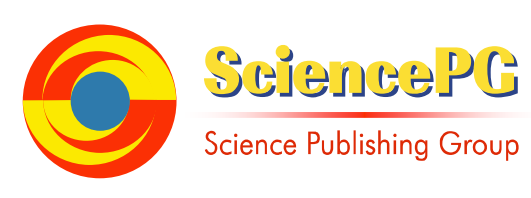

\title{
Comparative Economics Analysis of the Bt. Cotton V/S Conventional Cotton Production in Khairpur District, Sindh, Pakistan
}

\author{
Sanaullah Noonari*, Ms. Irfana Noor Memon, Mukhtiar Ali Bhatti, Moula Bux Perzado, \\ Shoaib Ahmed Wagan, Qurat-ul-ain Memon, Abass Ali Chandio, Asif Ahmed Sethar, \\ Ghulam Yasin Kalwar, Syed Taimoor Shah, Abdul Shakoor Jamroo
}

Department of Agricultural Economics, Faculty of Agricultural Social Sciences, Sindh Agriculture University, Tandojam Pakistan

\section{Email address:}

sanaullahnoonari@gmail.com (S. Noonari)

\section{To cite this article:}

Sanaullah Noonari, Ms. Irfana Noor Memon, Mukhtiar Ali Bhatti, Moula Bux Perzado, Shoaib Ahmed Wagan, Qurat-ul-ain Memon, Abass Ali Chandio, Asif Ahmed Sethar, Ghulam Yasin Kalwar, Syed Taimoor Shah, Abdul Shakoor Jamroo. Comparative Economics Analysis of the Bt. Cotton V/S Conventional Cotton Production in Khairpur District, Sindh, Pakistan. International Journal of Business and Economics Research. Vol. 4, No. 3, 2015, pp. 72-85. doi: 10.11648/j.ijber.20150403.11

\begin{abstract}
Cotton is an important cash crop which covers 35 million hectares of land. Major objectives of the study were to examine the role of determinants of cotton yield to asses' financial gain from Bt.cotton comparing with conventional Cotton. District Khairpur was selected for the present study where both Bt.cotton and conventional cotton varieties are grown primary data on Bt. cotton and conventional cotton was collected from the farmers through personal interviews with the help of specially designed questionnaire. A simple random sampling technique was used to collect the data. Cobb-Douglas production function was used for yield analysis. Logit model was used to find the probability of Bt.cotton. Farmers growing Bt. cotton who had used seed rate (6-8) $\mathrm{kg}$ per acre were 46.66 percent, while 53.33 percent had used seed rate (9-10) $\mathrm{kg}$ per acre. Conventional cotton who had used seed rate (6-8) $\mathrm{kg}$ per acre was 66.66 percent while 33.33 percent had used seed rate (9-10) $\mathrm{kg}$ per acre. Total costs per acre in Bt.cotton sown were greater than the conventional Cotton activities, total costs incurred in the conventional cotton were far lower (about 26 percent lower) than Bt.cotton. On an average higher yield (40 mounds per acre) was obtained in Bt.cotton sown than conventional cotton yield ( 25 mounds per acre). Price gained per mounds was almost the same in two cotton activities. Higher profit was observed in Bt. cotton and very low profit was obtained in conventional cotton.
\end{abstract}

Keywords: Cotton, conventional, Bt. Technology, Resource Use Efficiency, Decomposition of Output Change, Sindh

\section{Introduction}

The economy of Pakistan is mainly dependent on cotton and textile sector. Pakistan is the fourth largest cotton producer in the world. However, agriculture is the backbone of Pakistan's economy. Not with standing its declining share in GDP, agriculture is still the single largest sector of the economy, Contributing 21 percent to GDP. It also contributes significantly to Pakistan's export earnings. Not only that 45 percent of the work force of the country is employed in agriculture but also 60 percent of the country's population living in rural areas is linked with agriculture for their livelihood (GOP, 2012).

Bt. Cotton Bacillus thuringiensis is developed by Genetic
Engineering techniques (Biotechnology), Bt. cotton contains genes from Bacillus thuringiensis (Bt). Eight countries commercially grow Bt. cotton (USA, Australia, China, India etc.). Protein of this gene is deadly for the Chewing Pests I.e. American, Army, Pink and Spotted worm but not for sucking pest like Meal bug etc. Bacillus thuringiensis (or Bt.) is a Gram-positive, soil-dwelling bacterium, commonly used as a biological pesticide; alternatively, the Cry toxin may be extracted and used as a pesticide. The fiber is almost pure cellulose. Under natural conditions, the cotton bolls will tend to increase the dispersion of the seeds. The plant is a shrub native to tropical and subtropical regions around the world, 
including the Americas, Africa, and India. The greatest diversity of wild cotton species is found in Mexico, followed by Australia and Africa. Cotton was independently domesticated in the Old and New Worlds. The English name derives from the Arabic (al) quit which began to be used circa 1400 AD. The Spanish word, "algodón", is likewise derived from the Arabic (Metcalf and Allan A, 1999).

The bacterium Bacillus thuringiensis (Bt.) naturally produces a chemical harmful only to a small fraction of insects, most notably the larvae of moths and butterflies, beetles, and flies, and harmless to other forms of life. The gene coding for Bt. cotton toxin has been inserted into cotton, causing cotton to produce this natural insecticide in its tissues In many regions, the main pests in commercial cotton are lepidopteron larvae, which are killed by the Bt. cotton protein in the transgenic cotton they eat. This eliminates the need to use large amounts of broad-spectrum insecticides to kill lepidopteron pests (some of which have developed parathyroid resistance). This spares natural insect predators in the farm ecology and further contributes to no insecticide pest management. Bt. cotton is ineffective against many cotton pests, however, such as plant bugs, stink bugs, and aphids; depending on circumstances it may still be desirable to use insecticides against these (Anonymous, 2003).

Most of the Bt. cotton varieties were marketed with wrong notation of confrontation to all pests. In some instances Bt. cotton seed was mixed with non Bt. cotton seed and exaggerated the yield. Different varieties Sitars, ARS-802, CEMB-1, CEMB-2, FH-113, Neelum-121, ARS-703, MG-6 and Hybrid Bt. GN-31 and GN-2085 are the only Bt. cotton varieties/hybrid which is being introduced in Pakistan during next crop season following the rules and regulations designed by Federal and Provincial governments (GOP, 2010). Cotton production has decreased from 12,913 thousand bales in 2010 to 11,460 thousand bales in 2011, showing a decrease of 11.3 percent. Cotton production has decreased from 12,913 thousand bales in 2010 to 11.460 thousand bales in 2011, showing a decrease of 11.3 percent (GOP, 2011).

Sindh is expected to produce five million bales of cotton this year going by the seasonal sowing trend in areas commanded by the Kotri Barrage. However, this will largely depend on favorable weather conditions and regular supply of irrigation water. Cotton production has remained below normal due to floods and heavy rains over the past two years. Tharparker has achieved 105 per cent the targeted sowing, Umerkot 102 per cent, Tando Mohammad Khan 99 per cent, Matiari 97 per cent, Thatta 95 per cent, Hyderabad 85 per cent, Badin 80 per cent and Jamshoro 79 per cent, reveals the data released by the agriculture department. It said that in the cotton belt of upper Sindh, the sowing percentage is not so high except in Benazirabad (Nawabshah) with 95 per cent of the targeted area. Among other areas Khairpur has reported 85 per cent sowing, Naushero Feroz 76 per cent, Sukkar 85 per cent and Ghotki 40 per cent. Overall, against a sowing target for the current season at 650,000 hectares cotton plantation has reached 499,331 hectares by June 15, giving a target of 77 per cent.

\section{Objectives}

The objectives of the study were as follows:

1. To examine the role of determinants affecting cotton yield.

2. To compare the financial gains from two cotton activities (conventional cotton, Bt. cotton).

3 . To determine the impact of early sowing of Bt. cotton.

4. To suggest some policy measures to improve the situation.

\section{Materials and Methods}

The study was carried out to investigate the comparative analysis of the economics of Bt. Cotton V/S conventional Cotton production district of Sindh. The study focused on the determinants affecting cotton yield and to compare the financial gains from two cotton activities (Conventional cotton, Bt. cotton).

\subsection{Study Area}

The study was based on primary data. The data was collected through field survey using face to face interview with farmers simple 60 producers of cotton was selected Small, medium and large farmers were selected from each of two taluka so that sample could represent all categories of farmers.

\subsection{Methodological Framework}

The study was carried out by the use of primary data from the cotton growing farmers. This section contains two major segments. The first segment includes sampling method and data collection while analysis of the data is described in second segment.

\subsection{Questionnaire Development}

In all statistical surveys questionnaires are considered as the medium for recording the information obtained in a standardized manner. Keeping in view the comparative analysis of the economics of Bt. Cotton V/S conventional Cotton production district of Sindh questionnaire was developed; Questionnaire included important questions to obtain information about energy consumption pattern in wheat production along with other socio-economic characteristics of the farm house hold.

\subsection{Collection of Data}

Information about Cotton production and other necessary aspects was collected crop and operation wise, by employing comprehensive and pre tested questionnaire. In order to enhance the response rate, data was collected through interview. Although questionnaire was prepared in English language while the interview with respondents was done in local language i.e. Sindhi. Different features were covered in the questionnaire. 


\subsection{Socio Economic Characteristics}

The status of the sample respondents can be well described through socio economic characteristics. In this study, different indicators of respondent's socio economic features identified:

\subsubsection{Family Size}

Family size is an important socio-economic indicator that affects the agricultural activities. Family size means how many members are there in a household. Labour is mostly taken from farmer's family; therefore, household size has considerable impact on farming activities.

\subsubsection{Farm Size}

Land holding is another important indicator of production. Land holding means the total area where farming operations are performed. Three type of farmers are categorizes here: small farmers having land up to 12.5 acres, medium farmers having 12.5 to 25 acres and large farmers having more than 25 acres.

\subsubsection{Education of Farmer}

Education is the most important factor contributing to the production. Education means schooling years completed by a person to acquire knowledge. Educated persons can make better decisions, can take calculated risk and can adopt better technology of production.

\subsubsection{Bt. Cotton Training Received}

Bt. cotton training has ample impact on Bt. cotton production. With the Bt. cotton training farmers can manage Bt. cotton crop wisely and can get larger production benefits. Bt. cotton is also included as dummy variable in the model.

\subsubsection{Farming Experience of Farmer}

The experience of the farmer influence the yield obtained. Farmers have faced many problems in past and they know how to cope with them.

\subsubsection{No. of Cultivations}

No of cultivation has extensive impact on production. Land preparation is very important determinant and has significant impact on production. Before sowing any crop appropriate land preparation is very necessary.

\subsection{Planting Method}

Planting method also affects the yield. For the plantation of cotton there are two methods; plantation by drill and the other manual plantation. Planting method included as dummy variable in the model.

\subsection{Seed Rate}

Appropriate seed usage is very important for optimum level of production. Quality and quantity of seed both have significant impact on production.

\subsection{Fertilizers Use}

Fertilizers have substantial impact on production. Adequate fertilizer use decision is very important for crop production. Excessive use of fertilizers has negative impact on production, pollutes the underground water as well as surface water and hence the environment. Adequate level of fertilizer use is necessary for optimum level of production.

\subsection{Use of Pesticides (No. of Sprays)}

Cotton crop is prone to pests. Pesticides play important role to kill the pests and have significant effect on yield. Therefore pesticides are included as predictor. Farmers use excessive pesticides on cotton crop which is harmful for both farmers and to the environment. Irrigation is very essential element to determine the crop yield. Without irrigation there is no considerable output can be obtained. There are two sources of irrigation; canal water irrigation is charged by the government at fixed rate (Muamla) and tub-well irrigation costs on hourly bases.

\subsection{Data Analysis Techniques}

It is very important to use an appropriate model for research. The legit and probity model are used to find the probability of a decision (probability of early sowing of Bt. cotton). 'In practice many researchers choose the logit model because of its comparative mathematical simplicity (Gujrati and Sangheeta, 2003). So, logit model was used to find the probability of Bt. cotton. Logistic regression is useful for situations in which researcher wants to be able to predict the presence or absence of a characteristic or outcome based on values of a set of predictor variables. Logistic regression coefficients can be used to estimate the odd ratios for each of the independent variables in the model (Rasool, 2010). A two predictor logistic model was fitted to the data to test the research hypothesis regarding the relationship between the dependent variable (preference of farmers about early sowing of Bt. and Conventional cotton) and independent variables.

The general linear form of logic model is given below:

$$
\mathrm{L}_{\mathrm{i}}=\ln \left\{\mathrm{P}_{\mathrm{i}} /\left(1-\mathrm{P}_{\mathrm{i}}\right)\right\}=\mathrm{Z}_{\mathrm{i}}=\beta_{0}+\Sigma \beta_{\mathrm{i}} \mathrm{X}_{\mathrm{i}+} \mu_{\mathrm{i}}
$$

$\mathrm{L}$ is the log of odds ratio, is not only linear in $\mathrm{X}$ but also linear in parameters. $\mathrm{L}$ is called the logic, and hence the name logic model. $\mathrm{P}$ is the dependent variable used to check preference about Bt. cotton sowing in February-March, $\mathrm{P}=1$ if the farmer prefer $\mathrm{Bt}$ cotton and $\mathrm{P}=0$ otherwise. In $\left\{\mathrm{P}_{\mathrm{i}} /\left(1-\mathrm{P}_{\mathrm{i}}\right)\right\}$ is the log of odds ratio simply $\mathrm{P}_{\mathrm{i}} /\left(1-\mathrm{P}_{\mathrm{i}}\right)$ odds ratio in favor of sowing Bt. cotton - the ratio of the probability that a farmer will sow Bt. cotton in February-March to the probability he will not sow in February-March. The specific form of this relationship is given as:

$$
\begin{gathered}
\text { In }\left\{P /(1-P)>=a_{0}+a_{1} Z_{1}+a_{2} Z_{2}+a_{3} Z_{3}+a_{4} Z_{4}+a_{5} Z_{5}+a_{6} Z_{6}+\right. \\
a_{7} Z_{7}+a_{8} Z_{8}
\end{gathered}
$$

Where; $a_{0}=$ Intercept term of the model.

$a_{1}, a_{2}, a_{3} a_{4}, a_{5}, a_{6}, a_{7}$ and $a_{8}$ are the parameters to be estimated.

$Z_{1}$ Age of the farmer

(Years) 


$\begin{array}{ll}\mathrm{Z}_{2}=\text { Family Size } & \text { (Numbers) } \\ \mathrm{Z}_{3}=\text { Education of Farmer } & \text { (Years) } \\ \mathrm{Z}_{4}=\text { Own Tractor } & \text { (Assets) } \\ \mathrm{Z}_{5}=\mathrm{Bt} \text { Training Received by the Farmer } & \text { ( } 1 \text { if Yes, 0 if No) } \\ \mathrm{Z}_{6}=\text { Farming Experience } & \text { (Years) } \\ \mathrm{Z}_{7}=\text { Income of Farmer } & \text { (Rupees) } \\ \mathrm{Z}_{8}=\text { Farm size of the farmer } & \text { (Acres) } \\ \varepsilon_{\mathrm{i}}=\text { Stochastic error term. } & \end{array}$

Cobb Douglas production function was used for the production analysis. In agriculture output obeys the law of diminishing marginal returns with the use of different variable inputs. Cobb Douglas production function holds good for such type of analysis, therefore, Cobb Douglas production function model was used for analysis of the data. The general form of the Cobb Douglas production function is given below (Gujrati and Sangheeta, 2003):

$$
\mathrm{Y}=\beta_{0} \mathrm{X}_{\mathrm{i}}{ }^{\beta \mathrm{i}} \mathrm{e}^{\mu \mathrm{\mu i}} \quad \text { here } \mathrm{i}=1,2,3, \ldots . . \mathrm{n}
$$

The linear form of the Cob Douglas production function is given below;

$$
\text { In } Y=\beta_{\mathrm{o}}+\beta_{1} \operatorname{In} X_{1}+\beta_{2} \operatorname{In} X_{2}+\beta_{3} \operatorname{In} X_{3}+\beta_{4} \operatorname{In} X_{4}+\beta_{5}
$$
$\operatorname{InX}_{5}+\beta_{6} \ln X_{6}+\beta_{7} \operatorname{In} X_{7}+\beta_{8} \operatorname{In} X_{8}+\beta_{9} \operatorname{In} X_{9}+\beta_{10} \operatorname{In} X_{10}+\beta_{11} D_{1}+\beta_{12}$ $\mathrm{D}_{2}+\mu_{\mathrm{i}}$

Where;

In $Y=\log$ of the dependent variable (output)

$\beta_{0}=$ Intercept term of the model

$\beta_{1} \beta_{2} \beta_{3} \beta_{4} \beta_{5} \beta_{6} \beta_{7} \beta_{8} \beta_{9} \beta_{10} D_{1}$ and $D_{2}$ are the parameters to be estimated.

$\mathrm{X}_{1}, \mathrm{X}_{2}, \mathrm{X}_{3}, \mathrm{X}_{4}, \mathrm{X}_{5}, \mathrm{X}_{6}, \mathrm{X}_{7}, \mathrm{X}_{8}, \mathrm{X}_{9}, \mathrm{X}_{10}, \mathrm{D}_{1}$ and $\mathrm{D}_{2}$ are the independent variables i.e.

$$
\begin{aligned}
& \mathrm{X}_{1}=\text { Family size } \quad \text { (Numbers) } \\
& \mathrm{X}_{2}=\text { Hired Labour } \quad \text { (Numbers) } \\
& \mathrm{X}_{3}=\text { Cultivation } \quad \text { (Numbers) }
\end{aligned}
$$

$$
\begin{array}{ll}
\mathrm{X}_{4}=\text { Seed rate } & \text { (Kilograms) } \\
\mathrm{X}_{5}=\text { Fertilizer use } & \text { (Bags) } \\
\mathrm{X}_{6}=\text { Irrigation } & \text { (Numbers) } \\
\mathrm{X}_{7}=\text { Use of Pesticides } & \text { (Number of sprays) } \\
\mathrm{X}_{8}=\text { Farm Size } & \text { (Acres) } \\
\mathrm{X}_{9}=\text { Income of the Farmer } & \text { (Rupees) } \\
\mathrm{X}_{10}=\text { Education } & \text { (Years) } \\
\mathrm{D}_{1}=\text { Bt. Training Received } & \text { (1 if Yes, } 0 \text { if No) } \\
\mathrm{D}_{2}=\text { Plating method } & \text { (1 if Manual sowing, 0 if }
\end{array}
$$

Drill sowing)

$\mathrm{D}_{1}$ and $\mathrm{D}_{2}$ are dummy variables.

$\mu_{\mathrm{i}}=$ Stochastic error term.

\section{Results}

Most of the farmers have adopted the Bt. cotton. They get greater benefits from Bt. cotton crop than other cotton growers. However certain elements influence the yield of cotton crop. Two types of cotton activities were performed in the study area. These activities were Bt. cotton and conventional cotton sown. Distribution of respondents with socio-economic variables and the influence of these socioeconomic variables on the production of cotton crop are discussed here.

\subsection{Family Size of the Respondents}

Family size is an important socio-economic indicator that affects the agricultural activities. Family size means the total no of household members residing. In farming the labour force is usually taken from family members that have a considerable impact on the production. Also larger family members can better manage the farming activities.

Table 1. Respondents distribution according to family size in the study area

\begin{tabular}{lllll}
\hline \multirow{2}{*}{ Family Size } & Bt. Cotton & \multicolumn{3}{c}{ Conventional Cotton } \\
\cline { 2 - 5 } & No. Respondent & Percent & No. Respondent & Percent \\
\hline Below 4 & 5 & 16.66 & 4 & 13.00 \\
$5-7$ & 12 & 40.00 & 8 & 26.66 \\
$8-10$ & 10 & 33.33 & 11 & 36.66 \\
Above 10 & 3 & 10.00 & 7 & 23.33 \\
Total & 30 & 100.00 & 30 & 100.00 \\
\hline
\end{tabular}

Table-1 shows that Bt.cotton there were 16.66 percent were less 4 members, 40.00 percent were 5-7 members, 33.33 percent were 8-10 members family size out of 30 farmers... only 10.00 percent were above 10.00 percent members family size while in case of conventional cotton were 13.00 percent were less 4 members, 26.66 percent were 5-7 members, 36.66 percent were $8-10$ member family size. Only 23.33 percent were above 23.33 percent member's family size out of 30 farmers.

\subsection{Farm Size of the Respondents}

Total farm size of the farmers has significant effect on yield. In Pakistan majority of the farmers are small farmers having land holdings less than 12.5 acres. Farm size affects managerial and farming activities. Larger farm size is difficult to manage. Three type of farmers are categorizes here; small farmers having land up to 10 acres, medium farmers having 12.5 to 25 acres and large farmers having more than 25 acres. 
Table 2. Respondents distribution according to farm size in the study area

\begin{tabular}{|c|c|c|c|c|}
\hline \multirow{2}{*}{ Farm Size } & \multicolumn{2}{|l|}{ Bt. Cotton } & \multicolumn{2}{|c|}{ Conventional Cotton } \\
\hline & No. Respondent & Percent & No. Respondent & Percent \\
\hline Small (8-10 acres) & 8 & 26.66 & 9 & 30.00 \\
\hline Medium(10-15 acres) & 16 & 53.33 & 14 & 46.66 \\
\hline Large(above -15 acres) & 6 & 20.00 & 7 & 23.33 \\
\hline Total & 30 & 100.00 & 30 & 100.00 \\
\hline
\end{tabular}

Table-2 shows that Bt. cotton there were 26.66 percent small farm size, 53.33 percent were medium farm size, 20.00 percent were large farm size out of 30 farmers. While in case of conventional cotton was 30.00 percent small farm sizes, 46.66 percent were medium farm size, 23.33 percent were large farm size out of 30 farmers.

\subsection{Education of the Respondents}

Education is the most important factor contributing to the production. Education means schooling years completed by a person to acquire knowledge.

Table 3. Respondents distribution according to education level in the study area

\begin{tabular}{|c|c|c|c|c|}
\hline \multirow{2}{*}{ Education } & \multicolumn{2}{|l|}{ Bt. Cotton } & \multicolumn{2}{|c|}{ Conventional Cotton } \\
\hline & No. Respondent & Percent & No. Respondent & Percent \\
\hline Illiterate & 3 & 10.00 & 5 & 16.66 \\
\hline Primary & 7 & 23.33 & 5 & 16.66 \\
\hline Middle & 5 & 16.66 & 8 & 26.66 \\
\hline Matriculation & 8 & 26.66 & 9 & 30.00 \\
\hline Above Matriculation & 7 & 23.33 & 3 & 10.00 \\
\hline
\end{tabular}

Table-3 shows that Bt.cotton there were 10.00 percent were illiterate, 23.33 percent primary and 16.66 percent were middle education. 26.66 percent were matriculation and above matriculation 23.33 percent out of 30 farmers. While in case of conventional cotton were 16.66 percent were illiterate, 16.66 percent primary and 26.66 percent were middle education. 30.00 percent were matriculation and above matriculation 10.00 percent out of 30 farmers.

\subsection{Farming Experience}

The experience of the farmer influence the yield obtained. Farmers have faced many problems in past and they know how to cope with them.

Table 4. Respondents distribution according to farming experience in the study area

\begin{tabular}{|c|c|c|c|c|}
\hline \multirow{2}{*}{ Farming Exp: } & \multicolumn{2}{|l|}{ Bt. Cotton } & \multicolumn{2}{|c|}{ Conventional Cotton } \\
\hline & No. Respondent & Percent & No. Respondent & Percent \\
\hline $5-10$ & 4 & 13.33 & 8 & 26.66 \\
\hline $11-15$ & 7 & 23.33 & 10 & 33.33 \\
\hline $16-20$ & 10 & 33.33 & 7 & 23.33 \\
\hline Above 20 & 9 & 30.00 & 5 & 16.66 \\
\hline Total & 30 & 100.00 & 30 & 100.0 \\
\hline
\end{tabular}

Table-4 shows that Bt. cotton growers having the experience of (5-10) years were recorded 13.33 percent, farmers having experience (11-15) years were 23.33 percent, farmers having experience (16-20) were recorded 33.33 percent and having experience above 20 years were 30.00 percent out of 30 farmers. Conventional cotton growers having the experience of (5-10) years were recorded 26.66 percent farmers having experience (11-15) years were 33.33 percent, farmers having experience (16-20) were recorded 23.33 percent and having experience above 20 years were
16.66 percent out of 30 farmers.

\subsection{No. of Cultivations}

Before plating any crop land preparation is pre-requisite for better production. Here cultivation means no. of cultivations is applied on land i.e. land leveling, ploughing, planking and secondary tillage. Here only no. of cultivations is considered. 
Table 5. Respondents distribution according to cultivation in the study area

\begin{tabular}{lllll}
\hline \multirow{2}{*}{ Cultivations No } & Bt. Cotton & & Conventional Cotton & Percent \\
\cline { 2 - 5 } & No. Respondent & Percent & No. Respondent & 33.33 \\
\hline $6-8$ & 12 & 40.00 & 10 & 53.33 \\
$9-11$ & 11 & 36.66 & 16 & 13.33 \\
Above 11 & 7 & 23.33 & 4 & 100.0 \\
Total & 30 & 100.00 & 30 & \\
\hline
\end{tabular}

Table-5 indicates that Bt. cotton growers who had cultivated their fields up to 6-8 times were 40.00 percent, 911 times were 36.66 percent and more than 1.1 limes were 23.33 percent out of 30 farmers. Conventional cotton growers who had cultivated their fields up to 6-8 times were 33.33 percent, 9-11 times were 53.33 percent and more than 1.1 limes were 13.33 percent out of 30 farmers.

\subsection{Planting Method}

Planting method also affects the yield. For the plantation of cotton there are two methods; plantation by drill and the other manual plantation. Planting method included as dummy variable in the mode.

Table 6. Respondents distribution of the farmers to planting method in the study area

\begin{tabular}{|c|c|c|c|c|}
\hline \multirow{2}{*}{ Planting Method } & \multicolumn{2}{|l|}{ Bt. Cotton } & \multicolumn{2}{|c|}{ Conventional Cotton } \\
\hline & No. Respondent & Percent & No. Respondent & Percent \\
\hline Drill & 17 & 56.66 & 09 & 30.00 \\
\hline Manual & 13 & 43.33 & 21 & 70.00 \\
\hline Total & 30 & 100.00 & 30 & 100.00 \\
\hline
\end{tabular}

Table-6 proves that Bt. cotton farmers who had sown cotton crop with drill were found 56.66 percent, while manually sowing Bt. cotton were found 43.33 percent. Conventional cotton farmers who had sown cotton crop with drill were found 30.00 percent, while manually sowing were found 70.00 percent the cotton.

\subsection{Seed Rate}

Seed is essential input for crops yield. Appropriate seed use is very crucial to determine the production of crop. Bt. Cotton growers relatively purchase the expensive seed and conventional cotton growers use their home produced seed.

Table 7. Respondents distribution according to seed rate kg per acre in the study area

\begin{tabular}{lllll}
\hline \multirow{2}{*}{ Seed Rate (Kg) acre } & Bt. Cotton & & Conventional Cotton & Percent \\
\cline { 2 - 5 } & No. Respondent & Percent & No. Respondent & 66.66 \\
\hline $6-8$ & 14 & 46.66 & 20 & 33.33 \\
$9-10$ & 16 & 53.33 & 10 & 100.00 \\
Total & 30 & 100.00 & 30 & \\
\hline
\end{tabular}

Table-7 illustrates that farmers growing Bt. cotton who had used seed rate (6-8) $\mathrm{kg}$ per acre were 46.66 percent, while 53.33 percent had used seed rate (9-10) $\mathrm{kg}$ per acre. Conventional cotton who had used seed rate (6-8) $\mathrm{kg}$ per acre was 66.66 percent while 33.33 percent had used seed rate (910) $\mathrm{kg}$ per acre.

\subsection{Use of Fertilizers}

Now a day, due to intensive cropping land is deficient in nutrients. Adequate application of fertilizers enhances the yield so it is vital element in determining crop yield. In find many fertilizers have been used (Di-ammonium Phosphate (DAP), Urea, Single Super Phosphate (SSP), Triple Supper Phosphate (TSP) etc.). The fertilizers have positive impact on cotton crop yield.

Table 8. Respondents distribution according to fertilizer application in the study area

\begin{tabular}{lllll}
\hline \multirow{2}{*}{ Fertilizers (Bags) } & Bt. Cotton & \multicolumn{3}{c}{ Conventional Cotton } \\
\cline { 2 - 5 } & No. Respondent & Percent & No. Respondent & Percent \\
\hline $0-2$ & 6 & 20.00 & 4 & 13.33 \\
$2-3$ & 14 & 46.66 & 15 & 50.00 \\
Above 3 & 10 & 33.33 & 11 & 36.66 \\
Total & 30 & 100.00 & 30 & 100.00 \\
\hline
\end{tabular}

Table- 8 gives an idea about the fertilizer usage of the respondents according to Bt. and conventional cotton fields, from total of 60 farmers growing Bt. cotton had used fertilizers (0-2)-bags per acre were 20.00 percent, while
46.66 percent had used fertilizers (2-3) bags per acre and 33.33 percent farmers had used fertilizers above 3 bags per acre. Conventional cotton had used fertilizers (0-2)-bags per acre were 13.33 percent while 50.00 percent had used 
fertilizers (2-3) bags per acre and 36.66 percent farmers had used fertilizers above 3 bags per acre.

\subsection{Use of Pesticides (No. of Sprays)}

Cotton crop is prone to pests. Pesticides play important role to kill the pests and have significant effect on yield. Therefore pesticides are included as predictor. Farmers use Excessive pesticides on cotton crop which is harmful for both farmers and to the environment.

Table 9. Respondents distribution according to pesticides use in the study area

\begin{tabular}{lllll}
\hline \multirow{2}{*}{ Sprays (No.) } & Bt. Cotton & & Conventional Cotton & Percent \\
\cline { 2 - 5 } & No. Respondent & Percent & No. Respondent & 23.33 \\
\hline $2-3$ & 4 & 13.33 & 7 & 40.00 \\
$4-5$ & 14 & 46.66 & 12 & 36.66 \\
Above 6 & 12 & 40.00 & 11 & 100.00 \\
Total & 30 & 100.00 & 30 & \\
\hline
\end{tabular}

Table- 9 demonstrates the pesticides use of the respondents according to Bt. and conventional cotton fields. From total 60 farmers 'growing Bt. cotton had used pesticides (2-3) times per acre were 13.33 percent, while 46.66 percent had used pesticides (4-5) times per acre and 40.00 percent farmers had used pesticides above 6 times per acre. Conventional cotton had used pesticides (2-3) times per acre were $23.33 \%$, while 40.00 percent had used pesticides (4-5) times per acre and
36.66 percent farmers had used pesticides above 6 times per acre.

\subsection{No. of Irrigations}

Irrigation means watering the crop. Irrigation is very essential element to determine the crop yield. There are two sources of irrigation; canal water irrigation.

Table 10. Respondents distribution according to irrigation in the study area

\begin{tabular}{|c|c|c|c|c|}
\hline \multirow{2}{*}{ Irrigations (No.) } & \multicolumn{2}{|l|}{ Bt. Cotton } & \multicolumn{2}{|c|}{ Conventional Cotton } \\
\hline & No. Respondent & Percent & No. Respondent & Percent \\
\hline $6-8$ & 14 & 46.66 & 11 & 36.66 \\
\hline $9-11$ & 11 & 36.66 & 13 & 43.33 \\
\hline $12-14$ & 5 & 16.66 & 6 & 20.00 \\
\hline Total & 30 & 100.00 & 30 & 100.00 \\
\hline
\end{tabular}

Table-10 that Bt. cotton growers who had irrigated their fields (6-8) no. of times were 46.66 percent, (9-11) no. of times was 36.66 percent and who had irrigated (12-14) was 16.66 percent. Conventional cotton growers who had irrigated their fields (6-8) no. of times were 36.66 percent, (9-11) no. of times was 43.33 percent and who had irrigated (12-14) were 20.00 percent.

\subsection{Cobb-Douglas Production Function; Variable's Effect on Yield}

\subsubsection{Bt. Cotton (Model Estimation)}

$\ln \mathrm{Y}=1.693+0.067 \ln \mathrm{X}_{1}+0.013 \ln \mathrm{X}_{2}-0.053 \ln \mathrm{X}_{3}+0.039$

$\ln \mathrm{X}_{4}+0.003 \ln \mathrm{X}_{5}+0.236 \ln \mathrm{X}_{6}+0.013 \ln \mathrm{X}_{7}-0.015 \ln \mathrm{X}_{8}+0.041$

$\mathrm{InX}_{9} 0.019 \mathrm{InX}_{10}+0.087 \ln \mathrm{X}_{11}+0.052 \mathrm{Di}+0.037 \mathrm{D}_{2}+\mathrm{ui}$

Cobb-Douglas production function was used to determine the factors affecting yield. Partial regression coefficients, their standard errors and their $\mathrm{t}$-values are presented in the Table.

The coefficient of the log of family size has the value 0.67 with positive sign. The results revealed that family size is significant at one percent. By one percent increase in family size there was 0.67 percent positive contribution in yield. This shows that family size has significant effect on cotton yield.

The coefficient of the log of number of hired laborers is 0.013 . Its sign is positive. This value is highly significant at zero percent significance level. By increasing one percent of hired labour the yield of Bt-Feb increased by the .013 percent. This shows that yield can be enhanced by increasing the hired labour.

Table 11. Results of Regression Analysis (Bt. Cotton)

\begin{tabular}{|c|c|c|c|c|c|}
\hline \multirow{2}{*}{ Variables } & & \multicolumn{2}{|c|}{ Unstandardized Coefficients } & \multirow{2}{*}{ t- value } & \multirow{2}{*}{ Sig. } \\
\hline & & B & Std. Error & & \\
\hline Constant & & 1.693 & .246 & 6.8948 & .000 \\
\hline Log of Family Size & $\operatorname{LnX}_{\mathrm{i}}$ & .067 & .036 & 1.851 & .067 \\
\hline Log of Labour & $\mathrm{LnX}_{2}$ & .013 & .003 & 4.712 & 0.000 \\
\hline Log of Cultivation & $\operatorname{LnX}_{3}$ & .053 & .052 & $-\mathrm{I} .019 \mathrm{NS}$ & 0.311 \\
\hline Log of Seed Rate & $\mathrm{LnX}_{4}$ & .039 & .065 & $.602 \mathrm{NS}$ & .549 \\
\hline Log of Fertilizers & $\operatorname{LnX}_{5}$ & .030 & .055 & 1.532 & .153 \\
\hline Log of Irrigation & $\operatorname{LnX}_{6}$ & .236 & .059 & 3.975 & .000 \\
\hline Log of Pesticides & $\operatorname{LnX}_{7}$ & .013 & .027 & $.482 \mathrm{NS}$ & .631 \\
\hline Log of Farm Size & $\mathrm{LnX}_{8}$ & .015 & .011 & 1.406 & .163 \\
\hline
\end{tabular}




\begin{tabular}{llllll}
\hline \multirow{2}{*}{ Variables } & & \multicolumn{2}{c}{ Unstandardized Coefficients } & \multirow{2}{*}{ t- value } & Sig. \\
\cline { 3 - 4 } & & B & Std. Error & 2.067 & .041 \\
Log of Income of Farmer & $\mathrm{LnX}_{9}$ & .041 & .020 & $-.561 \mathrm{NS}$ & .576 \\
Log of Farming Experience & $\mathrm{LnX}_{10}$ & -.019 & .033 & 1.604 & .112 \\
Log of Education of Farmer & $\mathrm{LnX}_{11}$ & .087 & .054 & 2.681 & .009 .045 \\
Planting Method & $\mathrm{D} 1$ & .052 & .019 & 2.030 \\
Bt Cotton Training & $\mathrm{D} 2$ & .037 & .018 & 0.834 \\
R2 & 0.853 & & Adjusted R2 & 0.000 \\
F Value & 43.821 & & Significance & \\
\hline
\end{tabular}

The coefficient of the log of farm income of the farmer is noted 0.041 having positive sign. This value is significant at 5 percent level of significance. One percent increases in income of farmer the yield- increased by 0.041 percent. This shows that income has significant effect on cotton yield.

Method of planting have played important role in yield. Its coefficient has the value 0.052 with positive sign. It is significant at one percent. By using manual method of sowing the yield of cotton has been increased by .052 percent. This shows that the method of plating has significant effect on the yield. Significant differences were observed in plant population and yield as a function of seeding rate. A linear increase in yield with plant population was observed (Norton, 2001).

The coefficient of Bt. cotton training is 0.037 and has positive sign. Bt.cotton training is significant at 5 percent indicated that those farmers who get $\mathrm{Bt}$ cotton training increased the yield by .037 percent. The effect of farmer training is more distinct than those of the technology alone (Lifengac, 2007).

The coefficient of the log of education of farmers is 0.087 . It has positive sign. Level of education of farmers is significant at one percent... By increasing one percent in education of the farmers the yield increased by .087 percent. Farooqi (2009) also found that education has positive impact on yield. This is also related with the study of Qaim and Alain (2005) educated farmers are in better position to select appropriate inputs and their timely application. Thereby they were getting higher yields.

The other variables cultivation, seed rate, pesticide and farming experience have no significant impact on yield.

$\mathrm{R}$ is the measure of the goodness of fit of the model. $\mathrm{R}$ calculated from the model shows that 85 percent variation in the yield of Bt cotton sown was due to explanatory variables. Remaining $15 \%$ change in yield was due to other factors that were not included in the model.

The model also indicates that the production function fit well to the given data set. Similarly, F value is statistically greater than zero with value of 43.821 that was highly Significant at zero percent level of significance. This implies that the production function used in this study was statistically significant.

\subsubsection{Conventional Cotton (Model Estimation)}

$\mathrm{LnY}-1.123+0.001 \ln \mathrm{X},+0.006 \ln \mathrm{X}_{2}+0.023 \operatorname{In} \mathrm{X}_{3}+0.061$
$\ln \mathrm{X}_{4}+0.002 \mathrm{I} 11 \mathrm{X} 5+0.160 \ln \mathrm{X}_{6}+0.347 \ln \mathrm{X}_{7^{-}}-0.002$
$\ln \mathrm{X}_{8}+0.017 \ln \mathrm{X}_{9}+0.004 \operatorname{InX}_{10}+0.004 \ln \mathrm{X}_{11}+0.008$

Cobb-Douglas production function was used to determine the factors affecting yield. Partial regression coefficients, their standard errors and t-values are given in the Table.

The coefficient of the log of number of hired laborers is 0.006 . Its sign is positive. It is evident from the results that number of laborers is highly significant at 1 percent significance level. By increasing one percent of labour the yield of conventional cotton can be increased by .006 percent. This shows that yield can be enhanced by increasing the hired labour.

The coefficient of the log of seed rate is 0.061 . Its sign is positive and is significant at 15 percent level of significance. One percent increase in seed rate has increased the yield 0.061 percent. This shows that seed rate has significant effect on cotton yield.

The coefficient of the log of number of irrigations is 0.160 with positive sign. Its value is highly significant at zero percent. By increasing the one percent application of water the yield increased by 0.160 percent. This is related to the study of Farooqi (2009).

The coefficient of the $\log$ of pesticides is 0.347 with positive sign. Pesticides have .highly significant effect on the yield of conventional cotton. Pesticides are significant at zero percent, one percent increase in the no. of pesticides the yield was increased by 0.347 percent. These results are similar to Bennet et al (2006) in India indicated that the expenditures on sprays generally increased cotton yield.

The coefficient of the log of farm income of the farmer is 0.060 having positive sign. Farmer's income is significant at 10 percent. By increasing one percent income of farmer the yield increased by 0.017 percent.

The coefficient of the $\log$ of education of farmers is 0.004. It has positive sign. Education of farmers is important factor in farming and significant at 15 percent. By increasing one percent in education the yield increased by .004 percent. 
Table 12. Results of Regression Analysis (Conventional Cotton)

\begin{tabular}{|c|c|c|c|c|c|}
\hline \multirow{2}{*}{ Variables } & & \multicolumn{2}{|c|}{ Unstandardized Coefficients } & \multirow{2}{*}{ t- value } & \multirow{2}{*}{ Sig. } \\
\hline & & B & Std. Error & & \\
\hline Constant & & 1.123 & .126 & 8.911 & .000 \\
\hline Log of Family Size & $\operatorname{LnX}_{1}$ & .001 &, 012 & $.017 \mathrm{NS}$ & .986 \\
\hline Log of Labour & $\operatorname{LnX}_{2}$ & .006 & .002 & 3.335 & .001 \\
\hline Log of Cultivation & $\operatorname{LnX}_{3}$ & .023 & .017 & $.998 \mathrm{NS}$ & .458 \\
\hline Log of Seed Rate & $\operatorname{LnX}_{4}$ & .061 & .033 & 1.835 & .050 \\
\hline Log of Fertilizers & $\operatorname{LnX}_{5}$ & .002 & .002 & $.916 \mathrm{NS}$ & .363 \\
\hline Log of Irrigation & $\operatorname{LnX}_{6}$ & .160 & .041 & 3.865 & .000 \\
\hline Log of Pesticides & $\operatorname{LnX}_{7}$ & .347 & .035 & 9.820 & .000 \\
\hline Log of Farm Size & $\operatorname{LnX}_{8}$ & -.002 & .006 & $-.235 \mathrm{NS}$ & .815 \\
\hline Log of Income of Farmer & $\operatorname{LnX}_{9}$ & .017 & .011 & 1.635 & .106 \\
\hline Log of Farming Experience & $\operatorname{LnX}_{10}$ & .004 & .012 & $.304 \mathrm{NS}$ & .762 \\
\hline Log of Education of Farmer & $\operatorname{LnX}_{11}$ & .004 & .003 & 1.446 & .152 \\
\hline Planting Method & D1 & .008 & .007 & $1.06 \mathrm{INS}$ & .292 \\
\hline Bt Cotton Training & D2 & .004 & .009 & $.440 \mathrm{NS}$ & .661 \\
\hline R2 & 0.828 & & Adjusted R2 & 0.801 & \\
\hline F Value & 31.00 & & Significance & 0.000 & \\
\hline
\end{tabular}

Number of cultivations is non-significant. However, its coefficient has value 0.023 with positive sign which is non significant indicates that differences in yield among tillage treatments were not significant in conventional cotton. The other variables family size fertilizer, farm size, farming experience, planting method and $\mathrm{Bt}$ cotton training also have no significant impact on yield of conventional cotton.

$\mathrm{R}^{2}$ is the measure of the goodness of fit of the model. $\mathrm{R}$ calculated from the model shows that 82 percent variation in the yield of conventional cotton due to explanatory variables. Remaining 18 percent change was due to other factors that were not included in the model.

The model of conventional cotton also indicates that the production function fit well to the given data set. Similarly, F value is statistically greater than zero with value of 31.00 that was highly significant at zero percent level of significance. This implies that the production function used in this study is overall statistically significant.

It is concluded from above discussion that variables cultivation, seed rate, pesticide and farming experience have no significant impact on yield of Bt cotton Feb-March sown while the variables cultivation, pesticide, farming experience and method of planting have no significant impact on yield of May sown cotton and variables family size, cultivation, fertilizers, farm size, farming experience, planting method and Bt cotton training have no significant impact on yield of conventional cotton.

\subsection{Comparative Economics Total Fixed Costs}

The cost is defined as the value of the production factors consumed or used to reach a final goal. Total fixed cost consists of costs that do not vary as output varies and that must be paid even if output is zero. These are payments that the firm must make in the short run, regardless of the level of output. Fixed cost can be traceable and common. The fixed costs are "fixed"' in the short-term. Land Value and Depreciation are explained below;

This heading includes the net value of cash and payments in kind for renting of land, buildings and other rights for the farm business.

Depreciation: Reduction in the value of capital goods over a one-year period due to physical wear and tear and also to obsolescence. Depreciation is when the value of assets usually decreases as time goes by. The amount or percentage it decreases by is called depreciation. The depreciation is calculated at replacement value (the new value at current price) before deduction of subsidies. It concerns plantations of permanent crops, farm buildings and fixed equipment, land improvements, machinery and equipment. There is no depreciation of land, forest land and circulating capital. All EU Member States use the linear depreciation method that diminishes the value of an asset by a fixed amount each period, until the net value is zero. It is the simplest calculation. Depreciation is usually calculated with different coefficients for buildings, technical equipment, machinery, etc

Table 13. Total Fixed Costs of two cotton activities

\begin{tabular}{lll}
\hline Total Fixed Costs & Bt. Cotton Sown) & Conventional Cotton \\
\hline Land value & 26535 & 25255 \\
Depreciation & 3465 & 1345 \\
Total & 30000 & 26600 \\
\hline
\end{tabular}

Table-13 shows the total fixed costs related to two cotton activities. Bt. cotton fixed costs were double (30000 Rs.) than other two cotton activities (26600 Rs.) because of whole year duration of the crop. 


\subsection{Total Variable Costs}

Total variable cost consists of costs that are zero when output is zero and vary as output increases (decreases). These costs relate to the cost incurred for the use of variable inputs. Variable costs includes costs of cultivation, costs of labour, cost on seed (seed price and seed treatment), costs of fertilizers, costs of intercultural practices, costs of irrigations,
Weedicides and pesticides costs, cotton picking cost, implicit costs and miscellaneous costs. Labour costs, implicit costs and miscellaneous costs are explained below.

There are two categories of farm labour; hired labour and unpaid labour. The cost of the first category includes wages, salaries, benefits and other associated costs, while family labour is included in the second one.

Table 14. Total variable costs of two cotton activities

\begin{tabular}{|c|c|c|c|c|c|c|}
\hline \multirow{2}{*}{ Total variable Costs Expenses } & \multicolumn{3}{|c|}{ Bt. Cotton } & \multicolumn{3}{|c|}{ Conventional Cotton } \\
\hline & Quantity & Price/Unit & Total & Quantity & Price/Unit & Total \\
\hline Cultivation (No.) & 10.35 & 558 & 5775 & 8.5 & 533 & 4531 \\
\hline Labour (No.) & 0.28 & 36000 & 10080 & 0.22 & 18000 & 3960 \\
\hline Seed $(\mathrm{Kg})$ & 8.02 & 348 & 2791 & 9.55 & 167 & 1595 \\
\hline Fertilizers (Bags) & 3.05 & 1624 & 4953 & 2.00 & 1839 & 3678 \\
\hline Intercultural (No.) & 4.59 & 680 & 3121 & 4.45 & 655 & 2915 \\
\hline Irrigations (No.) & 12.08 & 450 & 5436 & 7.01 & 425 & 2980 \\
\hline Pesticides (No.) & 4.12 & 1098 & 4524 & 8.02 & 800 & 6418 \\
\hline Picking cost (No.) & 8.5 & 617 & 5241 & 5.05 & 565 & 2855 \\
\hline Implicit costs & - & - & 17871 & & - & 8301 \\
\hline Misc. & - & - & 8378 & - & & 5201 \\
\hline Total & -- & - & 68677 & --- & -- & 42939 \\
\hline
\end{tabular}

\subsection{Implicit Costs}

Implicit cost is an opportunity cost. In economics, an implicit cost, also called an imputed cost, implied cost, or notional cost, is the opportunity cost that results from using an asset instead of renting, selling, or lending it. The term also applies to forgone income from choosing not to work. These are intangible costs that are not easily accounted for. Farm operators who are very successful could have a marginal value of time in farming that exceeds their implicit wage for off-farm work (Cesaro, 2008). In present study the implicit cost is an opportunity cost of farmers who manage the farm and of family labour working in agriculture. Here opportunity cost of farm manager (farmer) and family labour was included as implicit costs.

\subsection{Miscellaneous Costs}

Miscellaneous costs for labour and machinery include, for example, the costs of services provided by agricultural contractors, the purchase of small equipment or protective clothing, the purchase of detergents for general cleaning and general farm maintenance, the cost of running farm vehicles, etc.

Table reveals that total variable costs are varying activity wise. The table shows the average quantity performed in the fields and average total costs associated with them. More total variable costs (68677 Rs.) involved to prepare Bt cotton fields comparing with the other two activities while conventional cotton requires least cost (42939 Rs.) from three cotton activities .

\subsection{Total Costs}

In economics, and cost accounting, total cost describes the total economic cost of production and is made up of variable costs, which vary according to the quantity of a good produced and include inputs such as labour and raw materials, plus fixed costs, which are independent of the quantity.

Table 15. Total Cost associated with cotton activities

\begin{tabular}{lll}
\hline Total Cost & Bt. Cotton & Conventional Cotton \\
\hline Total Variable Cost / Acre (Rs.) & 68677 & 42939 \\
Fixed cost / Acre (Rs.) & 30000 & 26600 \\
Total Cost/Acre (Rs.) & 98677 & 69539 \\
\hline
\end{tabular}

Table-15 shows the total costs per acre associated with the production of cotton. Total costs are the sum of total variable costs and total fixed costs.

\section{Total Costs $=$ Total Variable Costs + Total Fixed Costs}

Total costs per acre in Bt. cotton sown were greater than the other two activities that were recorded 98677 rupees and the total costs incurred in conventional cotton were for lower (about $41 \%$ lower) than Bt. cotton. Sown were 69539 rupees. Prices were still amply high for adopters of Bt. cotton to make considerable gains in net income.

\subsection{Profit Gains}

Profit is a financial benefit that is realized when the amount of revenue gained from a business activity exceeds the expenses, costs and taxes needed to sustain the activity. Any profit that is gained goes to the business's owners, who may or may not decide to spend it on the business.

\section{Total Profit $=$ Total Revenue - Total Costs}

Here the total revenue is the total income gained per acre. 
Table 16. Profits / Gains from two cotton activities

\begin{tabular}{lllllll}
\hline Varieties & Yield/Acre (Monds) & $\begin{array}{l}\text { Price/Mond } \\
\text { (Rs.) }\end{array}$ & Income/Acre (Rs.) & $\begin{array}{l}\text { Total Cost/ Acre } \\
\text { (Rs.) }\end{array}$ & $\begin{array}{l}\text { Net Profit/ Acre } \\
\text { (Rs.) }\end{array}$ & BCR \\
\hline Bt. Cotton & 40.2 & 3865.70 & 155401 & 98677 & 56724 & 1.57 \\
Conventional Cotton & 28.5 & 3865.21 & 110158. & 69539 & 42619 & 1.30 \\
\hline
\end{tabular}

Table-16 shows the total yield obtained by the farmer per acre, price of the cotton per mounds, income gained by the farmer per acre, per acre total input costs associated with the production of cotton and net profit (economic profit) gained per acre. On an average higher yield was obtained in Bt. cotton sown 40.2 monds per acre and conventional cotton yield was low only28.5 monds per acre.

Price gained per mond was almost the same in three cotton activities. Income gained per acre in Bt.cotton was 155401 rupees, and income gained from conventional cotton was only 110158. Rupees. Higher profit of 56724 rupees was observed in Bt.cotton; while 42619 rupees was obtained in conventional cotton. BCR (Benefit Cost Ratio) shows the return on per rupee invested. Introduction of $\mathrm{Bt}$. cotton showed significant farm-level benefits. Aggregate benefits depended on adoption rate and yield advantage of Bt-cotton (Cabanilla, 2004).

\subsection{Cotton Yield Comparison of Two Cotton Activities}

Average yield comparison obtained from two cotton activities. Early growers of $\mathrm{Bt}$ cotton in were taking the highest yield 40.2 monds per acre, and conventional cotton growers were obtaining 28.5 monds per acre that is low yield due to pest attack and cotton curl leaf virus. Conventional cotton gave poor yield 18 monds/acre (Farooqi, 2009). There was 51.50 percent increase in Bt cotton yield while 18.07 percent increase was found in comparing with conventional cotton due to resistance against chewing pest and hence additional income to poor farmers in Khairpur district. Percentage increase in the yield 51.5 percent of $\mathrm{Bt}$ cotton than conventional cotton is similar to the results gained by Reddy (2011) indicated that productivity increase was significant that 51.16 percent more yield with the introduction of $\mathrm{Bt}$ cotton.

\subsection{Comparison of Total Income Received and Total Costs}

Compares total income and total costs. Farmers were growing B.t cotton have received larger income and conventional cotton growers. It is clear from the figure that Bt.cotton farmers have received (155401 Rs.) imposing higher costs (98677 Rs.) and conventional -cotton farmers got (75372 Rs.) costing (57939 Rs.)- The application of Bt. cotton increased the income from agriculture for farmers and also improved the households' livelihood (Wang, 2008).

Income, Total costs and Profit by Cotton Activities (Rs. / Acre)

The comparison of total income gained, total costs associated and profit gained from two cotton activities. Higher income (155401 Rs.), higher costs (98677 Rs.) and higher profits (56724 Rs.) were gained in sowing Bt. cotton but conventional cotton gave poor results lower income (75372 Rs.). Lower costs (57939 Rs.) and very low profits (17433 Rs.) were recorded. The question of higher cost of cultivation existed, and was confirmed, mainly because of high seed cost and not corresponding reduction in pesticide cost.

\section{Discussion}

Production of any crop depend upon soil structure, climatic condition, social organization, availability of resources, quality inputs and favorable marketing condition both in factor and product markets. It is, therefore, considered to have brief discussion of area and production levels of Bt. and conventional Cotton in various regions of Pakistan, production potentials, profile of study are before explaining survey results.

Study shows that overall cost of cultivation (sowing) and seed on Bt. cotton was high as compared to on Conventional cotton due to high seed rate. The use of fertilizer is more in Bt. as compared to conventional cotton. The pesticides cost was more in conventional as compared to Bt. Cotton due more application of pesticides in conventional cotton. Total cost of production on Bt. Cotton was Rs/Acre 98677 which was more than conventional cotton Rs/Acre 69539 due to more variable cost of Bt. cotton. Overall high yield was obtained $40.2 \mathrm{md} /$ acre from Bt. cotton is compared to $28.5 \mathrm{md} /$ acre by Conventional cotton. Total revenue of cotton production was received by the Bt. cotton growers Rs/Acre 155401 and conventional cotton growers were Rs/Acre 110158. Study results further indicate that Bt. cotton growers obtained higher Net Profit/ Acre (Rs.). 56724, as compared to conventional cotton growers were Rs/Acre. 42619. There was increase in Bt. cotton yield comparing with conventional cotton which gives additional income to poor farmers in District Khairpur.

Aziz et al. (2011) analyzed comparative performance of Bt. cotton with some elite conventional cotton cultivars under arid to semi-arid conditions. To identify the superior genotype, they studied the comparative growth and yield performance of four cotton cultivars namely, CIM-496, BH162, VH-144 and Bt-121, grown on sandy clay loam soil. The results revealed that plant growth parameters like plant height, number of bolls plant-1 and seed cotton weight boll-1, were differed significantly $(\mathrm{P}<0.05)$ among $\mathrm{Bt}$. and non-Bt. cotton cultivars. Seed cotton yield and fiber quality parameters such as maturity percentage, microware value, staple length and fiber strength and virus infection percentage were also significantly. Bt-121 had maximum value for seed cotton weight boll-1 and maturity percentage and produced 
$26 \%$ higher seed cotton yield than all other cultivars. Furthermore, it also showed 58\% less cotton leaf curl virus infection compared to other cultivars. BH-162 produced fiber with maximum length and fineness but it appeared most vulnerable to virus attack. It was concluded that Bt-121 performed best in most of the studied traits than other cultivars and might be recommended for cultivation in areas having arid to semi-arid climatic conditions.

\section{Conclusions}

This study was carried out to compare the economics of Bt. and Conventional Cotton based on the field survey in the cotton cropping zone of Sindh. The information was collected from selected Bt. and Conventional Cotton growers. The data was collected through personal interviews. Number of analytical techniques has been used to access comparative economic analysis of Bt. v/s conventional cotton production i.e. farm cost analysis, Net Return analysis; gross margin analysis.

Major findings are the differences in production cost between Bt. and Conventional cotton which were 98677 Rs/Acre of Bt.cotton and $69539 \mathrm{Rs} /$ Acre of Conventional cotton. Major differences in Bt.cotton production cost are related to higher seed prices, cultivation use on per acre, and other inputs expenditure. Bt.cotton production is related to the higher yield potential of Bt.cotton was 40 mounds/Acre as compared to Conventional cotton was 25 mounds/Acre while market price of both was nearly same i.e. 3865.70 Rs/mound for Bt.cotton and $3865.21 \mathrm{Rs} /$ mound for Conventional cotton.

The present study clearly indicates that Bt. cotton farmers were increasing farm yield and farm profit compared to Conventional cotton. Farmers were reducing cotton area that severely affected the cotton production. Farmers were focusing to increase the Bt.cotton area.

Therefore, it is suggested that more and more farmers should be trained and motivated to increase the production of cotton crop Farmers were unaware of proper combination of inputs and sowing time they either underutilized the inputs or over utilized and sow seed either very early or late of the season. For the promotion of cotton crop following strategy should be adopted:

- There is a need for Bt. cotton research programme. The scientists should make efforts for the genetic improvement and development of new varieties. Better genotypes should be made available to growers.

- Advising proper combination of inputs to the farmer and giving subsidy on the inputs will result in enhanced per acre yield of cotton, thus foreign exchange increase in Pakistan.

- Bt.cotton production can be enhanced by the provision of new technology at the doorstep of farmers.

- Farmers face the marketing problems. Government should make adequate policies and farmers must be involved while making these agricultural policies.

- The scientists should make efforts for the own Bt.cotton varieties, because of Bt. Seed was expensive for farmers.
- Government should provide subsidies on fertilizers and pesticides and other micro nutrients.

- There is need of proper guide to farmers about Bt.cotton so Government should provide and activate researchers and extension department for proper guideline of farmers.

\section{References}

[1] Adamczyk, J. J. and J. Gore. 2003. Varying Levels of Cry 1 Ac in Transgenic Bacillus thuringiensis Berliner (Bt) Cotton Leaf Bioassays. J. Agric. Urban Entomol, 20(2): 49-53.

[2] Ahmad, M. and U. Farooq. 2010. The State of Food Security in Pakistan: Future Challenges and Coping Strategies. Paper Submitted for Presentation at the 26th AGM and Conference of PSDE being held on 28-30 December 2010 in Islamabad, Pakistan.

[3] Arora, A. and S. Bansal. 2011. Diffusion of Bt Cotton in India: Impact of Seed Prices and Technological Development Discussion Paper 11-01.

[4] Aziz, A., N. Akhtar, M. Afzal, M. Ashraf, A.Tanveer, R. Ahmad, M. E. Safdar and S. Ahmad. 2011. Comparative performance of $\mathrm{Bt}$ cotton with some elite conventional cotton cultivars under arid to semi-arid conditions. African Journal of Agricultural Research, 5(6): 1600-1606

[5] Bashir, M. K., M. K. Naem and S. A. K. Niazi. 2010. Rural and Peri-Urban Food Security: A case of District Faisalabad of Pakistan. World Applied Sciences Journal, 9(4): 403-411

[6] Bennett, R., Y. Ismael, S. Morse and B. Shankar. 2004. Reductions in insecticide use from adoption of Bt cotton in South Africa: impacts on economic performance and toxic load to the environment. Journal of Agricultural Science, 142: 665-674

[7] Blessing, M. M. and M. S. Scott. 2003. Hidden health costs of pesticide use in Zimbabwe's smallholder cotton growers. Social Science and Medicine, 57: 1559-1571.

[8] Cabanilla, L. S., T. Abdoulaye and J. H. Sanders. 2004. Economic cost of non-adoption of Bt. cotton in West Africa: with special reference to Mali. Int. J. Biotechnology, Vol. X, No. X, 2004.

[9] Chakraborty, K., S. Misra, and P. Johnson. 2002. Cotton Farmers' Technical Efficiency: Stochastic and Nonstochastic Production Function Approaches. Agricultural and Resource Economics Review 31(2): 211-220

[10] Centeral Intelligence Agency (CIA). 2010. World Fact Book Independent US Government agency.

[11] Cesaro, L., S. Marongiu, F. Arfmi, M. Donati and M. G. Capelli. 2008. Cost of production. Definition and Concept. Farm Accountancy Cost Estimation and Policy Analysis of European Agriculture.

[12] Dawson, J. P. 2002. Nutrition in Pakistan estimating economic demand for calories in Pakistan. Journal of 'nutrition 1(1): 6466

[13] Dhillon, M. K. and H. C. Sharma. 2010. Influence of seed treatment and abiotic factors on damage to $\mathrm{Bt}$ and non- $\mathrm{Bt}$ cotton genotypes by the serpentine leaf miner Liriomyza trifolii (Diptera: Agromyzidae). 30(3): 127-130 
[14] Dong, H., W. Li, W. Tang and D. Zhang. 2004. Development of hybrid $\mathrm{Bt}$ cotton in China -A successful integration of transgenic technology and conventional techniques. Current science, vol. 86(6): 778-782

[15] Dutta, I., C. Gundersen, and P. K. Pattanaik. 2006. Measures of Food Insecurity at the Household Level Indranil. Research Paper No. 2006/95

[16] Du Rand, Nicolette (July 2009). Isolation of Entomopathogenic Gram Positive Spore Forming Bacteria Effective Against Coleoptera ( $\mathrm{PhD}$ Thesis). Pietermaritzburg, South Africa: University of KwaZulu-Natal

[17] Elbehri, A. and S. MacDonald. 2003. Transgenic cotton and crop productivity: A general equilibrium analysis for West and Central Africa. Paper prepared for presentation at the 6th International Conference on Global Economic Analysis The Hague, Netherlands, June 12-14, 2003.

[18] Farooqi, Z. 2009. Comparative performance of Bt cotton: Economics and environmental aspects. Student thesis department of Environmentel and Resource Economics, University of Agriculture Faisalabad. Pakistan

[19] Fitt, G. P. and L. Wilson. 2004. Integration of Bt cotton in IPM systems: an Australian perspective. Australian Cotton Cooperative Research Centre Narrabri, NSW, Australia.

[20] Flofs, J. L., F. Michel and V. Maurice. 2006. Impact of Bt cotton adoption on pesticide use by smallholders: A 2-year survey in Makhatini Flats (South Africa). 25: 984-988

[21] Frongillo, E. A., C. M. Olson, B. S. Rauschenbach and A. Kendall. 1997. Nutritional Consequences of Food Insecurity in a Rural New York State County. Institute for Research on Poverty discussion paper no. 1120-97

[22] Gandhi, V. P. and N, V. Namboodiri. 2006. The Adoption and Economics of Bt Cotton in India: Preliminary Results from a Study 2006 W.P. No. 2006-09-04

[23] Gouse, M., C. E. Pray and S. David. 2004. The Distribution of Benefits from Bt Cotton Adoption in South Africa. AgBio Forum, 7(4): 187-194

[24] GOP. 2009. Agriculture Statistics, (2008-09). Ministry of Food and Agriculture (Economic Wing), Government of Pakistan, Islamabad. Pakistan

[25] GOP. 2010. Economic Survey of Pakistan, (2009-10). Economic Advisor's Wing, Ministry of Finance, Government of Pakistan, Islamabad. Pakistan p. 13-17

[26] GOP. 2011. Economic Survey of Pakistan, (2010-11). Economic Advisor's Wing, Ministry of Finance, Government of Pakistan, Islamabad. Pakistan

[27] Goyne, P. J. 2003. Cotton/Grains Adoption Program. Milestone 4 Report June 2003.

[28] Gunningham, N. 2004. Cotton, Health and Environment: A Case Study of Self-Regulation. National research centre for OHS regulation, working paper 29.

[29] Gujrati, D. N. and Sangheetha. 2003. Basic Econometrics (4th Ed.). Me Graw Hill Book C, Inc. New York.

[30] Hillocks, R. 2009. Bt cotton and maize: Associated benefits and problems in the developing world. Arab Journal of Plant Protection, 27: 221-225.
[31] Huang, J., H. Ruifa, F. Cuihui, C. E. Pray and R. Scott. 2003. Bt cotton benefits, costs and impacts in China. IDS Working Paper 202.

[32] Huang, J., R. Hu, C. Pray, F. Qiao and S. Rozelle. 2003. Biotechnology as an alternative to chemical pesticides: a case study of Bt cotton in China. Agricultural Economics 29: 55-67.

[33] Huang, J., M. JianWei, H. Lin, Z. Wang, R. Chen, R. Hu, S. Rozelle and C. E. Pray. 2010. A decade of Bt cotton in Chinese fields: Assessing the direct effects and indirect externalities of Bt cotton adoption in China. 53(8): 981-991

[34] Hossain, F., E. P. Carl, L. Yanmei, FI. Jikun, F. Cunhui and H. Ruifa. 2004. Genetically Modified Cotton and Farmers' Health in China. 10:296-303.

[35] Hosmer, D. W. and S. Lemeshow. 2000. Applied Logistic Regression, New York : Wiley, ISBN 0471615536

[36] Ismael, Y., C. Thirtle, L. Beyers, R. Bennett, S. Morse, J. Kirsten, M. Gouse, L. Lin and J. Piesse. 2001. Smallholder adoption and economic impacts of Bt cotton in the Makhathini Flats, Republic of South Africa, Report for DFID Natural Resources Policy Research Programme Project R7946, London, UK.

[37] International Monetary Fund (IMF). 2011. Ranking of the world countries Washington D.C. Available at http://en.wikipedia.org/wiki/List of countries by GDP (PPP)

[38] James, C. 1998. Global review of commercialized transgenic crops. ISAAA Brief No.8 available at www.isaaa.org.

[39] Jost, P., D. Shurley, S. Culpepper and P. Roberts. 2008. Economic Comparison of Transgenic and Nontransgenic Cotton Production Systems in Georgia. Agronomy Journal, 100: $215-230$

[40] Lifengac, W., D. Pemslb and H. Waibel. 2007. The role of Farmer Training in the Diffusion of Biotechnology in Cotton in China: A Multi-period analysis. Conference on International Agricultural Research for Development.

[41] Long, J. S. 1997. Regression models for categorical and limited dependent variables p. 70-72

[42] Mina, U., A. Chaudhary, A. Kamra. 2011. Effect of Bt Cotton on Enzymes Activity and Microorganisms in Rhizosphere. Journal of Agricultural Science Vol. 3(l):96-J04

[43] Minard, C. J. 2000. A multiple logistic regression analysis of the cross sectional data 23(2):243-308

[44] Martinko, John M., eds. (2005). Brock Biology of Microorganisms (11th ed.). Prentice Hall. ISBN 978-0-13144329-7

[45] Norton, E.R., L. J. Clark and E. W. Carpenter. 2001. Planting Method and Seeding Rate Evaluation in Graham County.

[46] Pray, C. E., J. Huang, R. Hu and S. Rozelle. 2002a. Five years of $\mathrm{Bt}$ cotton in China the benefits continue. Plant J. 31: $423^{\wedge} 30$.

[47] Qaim, M. and D. Zilberman. 2003. Yield Effects of Genetically Modified Crops in Developing Countries. Science 299-900

[48] Qaim, M. 2003. Bt cotton in India: field trial results and economic projections. World Development, 31: 2115-2127. 
[49] Qaim, M. and A. deJanvry. 2003. Genetically modified crops, corporate pricing strategies, and farmers' adoption: the case of Bt cotton in Argentina. American Journal of Agricultural Economics, 85: 814-828.

[50] Qaim, M. and A. deJanvry. 2005. Bt cotton and pesticide use in Argentina: economic and environmental effects. Environment and Development Economics 10: 179-200.

[51] Rasool, F. 2010. Economics of seasonal and off seasonal Bt cotton production: Evidence from mixed cropping zone. Student thesis department of Environmentel and Resource Economics, University of Agriculture Faisalabad. Pakistan.

[52] Reddy, M. C, K. Tirapamma and K. G. Reddy. 2011. Socio economic impact of Bt cotton in Andhra Pradesh, India: a comparative study. International Journal of Plant, Animal and Environmental Sciences, 1: 126-130.

[53] Roh, JY; Choi, JY; Li, MS; Jin, BR; Je, YH (2007). "Bacillus thuringiensis as a specific, safe, and effective tool for insect pest control". Journal of microbiology and biotechnology 17 (4): 547-59.

[54] Riches, C. R. 2003. Evaluation of cotton management practices 2003. Project r8197 (fir part 3). Appendix 2. Onfarm validation of cotton ICM components.

[55] Statistical arm of the Food and Agriculture Organization (FAOSTAT). 2010. The United Nations, Ranking of agricultural commodities.

[56] Stone, G. D. 2010. Field versus Farm in Warangal: Bt Cotton, Higher Yields. World Development and Larger Questions. Vol. $\mathrm{xx}$, No. $\mathrm{x}, \mathrm{pp}$. $\mathrm{xxx}-\mathrm{xxx}$,
[57] Subramanian, A. and M. Qaim. 2009. Rural Poverty and Employment Effects of Bt Cotton in India. Contributed Paper prepared for presentation at the International Association of Agricultural Economists (IAAE) Conference Beijing, China, August 16-22, 2009

[58] Wang, S. and H. E. Babcock. 2006. Tarnishing Silver Bullets: Bt Technology Adoption, Bounded Rationality and the Outbreak of Secondary Pest Infestations in China. Selected paper prepared for presentation at the American Agricultural Economics Association annual meeting Long Beach, CA, July 22-26, 2006.

[59] Wang, G., W. Yuhong, G. Wangsheng, F. Michel and L. Weili. 2008. Impact of Bt Cotton on the Farmer's Livelihood System in China. ISSCRIInternational Conference.

[60] Williamson, S., A. Little, M. A. Ali, M. Kimanai, C. Meir and L. Oruko. 2003. Aspects of cotton and vegetable farmers' pest management decision-making in India and Kenya. International Journal oj Pest management, 49(3): 187-198

[61] Way, M. J. and H. F. vanEmden. 2000. Integrated pest management in practice pathways towards successful application. Crop Protection 19: 81-103 World Bank. 2010. World Development Indicators released. Available at http://data.worldbank.org/news/world-developmentindicators-2010-released.

[62] Yang, P., M. Ilesb, S. Yana and F. Jolliffe. 2005. Farmers' knowledge, perceptions and practices in transgenic Bt cotton in small producer systems in Northern China. Crop Protection 24: $229-239$. 